\title{
Corticolous green algae from tropical forest remnants in the northwest region of São Paulo State, Brazil ${ }^{1}$
}

\author{
NADIA MARTINS LEMES-DA-SILVA ${ }^{2,3}$, LUIS HENRIQUE ZANINI BRANCO ${ }^{2}$ and \\ ORLANDO NECCHI-JÚNIOR ${ }^{2}$
}

(received: March 18, 2009; accepted: March 11, 2010)

\begin{abstract}
Corticolous green algae from tropical forest remnants in the northwest region of São Paulo State, Brazil). The algae inhabit a wide variety of terrestrial environments and substrates; however the taxonomic knowledge for tropical regions is still scarce. This survey was conducted in ten forest remnants in São Paulo State where visible growths of algae and bryophytes were collected and studied for the main algal components of the communities. Results reveal the occurrence of nine species of green algae, distributed through the class Trebouxiophyceae (one species), Charophyceae (one species) and Ulvophyceae (seven species). Desmococcus olivaceus (Persoon ex Archerson) J. R. Laundon and Printzina effusa (Krempelhüber) Thompson \& Wujek are new records for Brazil. The most frequent organisms found in the areas pertain to Trentepohliales that is mainly represented by Trentepohlia species. On the basis of results found, it is recommended that such communities receive more attention in future investigations to improve the knowledge about this important group of primary producers.
\end{abstract}

Key words - Brazil, seasonal semideciduous forest, terrestrial algae, Trentepohlia

RESUMO - (Algas verdes corticícolas de remanescentes de floresta tropical na região noroeste do Estado de São Paulo, Brasil). As algas habitam uma grande variedade de ambientes e substratos terrestres; entretanto o conhecimento taxonômico para as regiões tropicais ainda é escasso. Esse levantamento foi conduzido em 10 fragmentos florestais no Estado de São Paulo, onde crescimentos visíveis de algas e briófitas foram coletados e os principais componentes da comunidade algal foram estudados. Os resultados revelaram a ocorrência de nove espécies de algas verdes, distribuídas nas classes Trebouxiophyceae (uma espécie), Charophyceae (uma espécie) e Ulvophyceae (sete espécies). Desmococcus olivaceus (Persoon ex Archerson) J. R. Laundon e Printzina effusa (Krempelhüber) Thompson \& Wujek são novos registros para o Brasil. Os organismos mais frequentes nas áreas pertencem a Trentepohliales, que foi representado principalmente por espécies de Trentepohlia. Baseado nos resultados encontrados, é recomendado que tais comunidades recebam mais atenção em investigações futuras para aumentar o conhecimento sobre esse importante grupo de produtores primários.

Palavras-chave - algas terrestres, Brasil, floresta estacional semidecidual, Trentepohlia

\section{Introduction}

Although algae are usually mainly known from marine and freshwater habitats, they also occur in a wide variety of terrestrial environments (Hoffmann 1989) where they form conspicuous growths in several surface types, including rocks, urban walls, metals, tree barks, leaves and animal hairs (López-Bautista et al. 2007).

The algae that inhabit terrestrial environments can be designed by different terms in literature as microbiotic crusts, cryptogrammic crusts, subaerial algae, aerophytic algae and terrestrial algae. Many of them are freely used as synonyms.

1. Part of the first author's MSc Thesis, Programa de Pós-graduação em Biologia Vegetal, Universidade Estadual Paulista, Campus de Rio Claro, SP, Brazil.

2. Universidade Estadual Paulista, Departamento de Zoologia e Botânica, Instituto de Letras, Biociências e Ciências Exatas, R. Cristóvão Colombo, 2265, 15054-000 São José do Rio Preto, SP, Brazil.

3._Corresponding author: nadialemes@gmail.com
Many aerophytic algae spend a majority of the vegetative life out of water, although their reproductive stages cannot be completed without water (Lewis \& McCourt 2004). Light and air humidity are considered the most influential ecological factors on the growth and development of these organisms, while temperature is viewed as a secondary one (Fritsch 1907, Islam 1960). According to Neustupa \& Škaloud (2008), the diversity of different algal groups is mainly influenced by light conditions and Trentepohliales are more adapted to nonshaded habitats.

Most studies on taxonomy and ecology of aerophytic algae were conducted in temperate areas (López-Bautista et al. 2007), with great emphasis on those occurring on soil (e.g. Metting 1981, Starks et al. 1981, Flechtner et al. 1998, Evans \& Johansen 1999, $\mathrm{Hu}$ et al. 2002). Some investigations focused on the algal flora from human constructions (buildings and monuments) because of their biodegradation effects (Ortega-Calvo et al. 1991, Gaylarde \& Gaylarde 1999, Crispim et al. 2003). 
Green algae are very successful in colonizing terrestrial habitats, despite Cyanobacteria is also very well represented. Other algal groups (e.g. Bacillariophyta) can be eventually found in such environment (Hoffmann 1989, Nakano et al. 1991, López-Bautista et al. 2007).

Amongst the green algae, members of Trentepohliales (Ulvophyceae) are the major components of terrestrial flora in the world (Fritsch 1907, Islam 1960, Akiyama 1971), living on tree trunks, rocks, leaves and fruits, and occurring at high abundance and diversity in tropical regions (López-Bautista et al. 2002). Because Trentepohliales is the mostly abundant algal group in terrestrial environment, especially in corticolous habitat, almost all the studies consider only this organisms and works about the whole community, including other algae and cyanobacteria, are very scarce (Neustupa \& Škaloud 2008). Recently, some studies on taxonomy and distribution of Trentepohliales have been developed in tropical areas as Hawaii (Rindi et al. 2005), different places in Africa (Rindi et al. 2006) and French Guiana (Rindi \& López-Bautista 2007, 2008). The knowledge of aerophytic Chlorophyta in Brazilian territory (São Paulo State area) is limited to the papers of Akiyama (1971), which reported eight species of Trentepohlia, and Bicudo \& Santos (2001), which recorded four species of Trentepohlia and one of Physolinum. The former paper does not offer information on the type of environments evaluated. The latter was conducted in an area with tropical forest renmant and corticolous, edaphic and epilithic habitats were sampled.

This study is part of a wider project dealing with fauna and flora of remnant forest fragments of the northwest region of São Paulo State. Considering the scarcity of investigations on aerophytic algae in tropical regions and particularly in Brazil, it was aimed to accomplish the taxonomic survey of the aerophytic green algae and cyanobacteria growing on trees of seasonal semideciduous forest fragments in the northwestern São Paulo State. The survey of cyanobacteria will be presented in a further article.

\section{Material and methods}

This survey was conducted in 10 fragments of seasonal semideciduous forest (A1 to A10) with different total areas (50 to 2000 ha) and located in the northwestern region of São Paulo State (table 1, figure 1).

Samples were collected between March and May 2007, considered the most favorable period for growth of the organisms, in a pre-determined 1 ha plot in each fragment.

Theoretically, algae can develop in any available and suitable substratum for growth in terrestrial environments. However, preliminary data obtained in previous samplings in selected fragments revealed that the occurrence of aerophytic organisms was limited to the tree barks. Algal masses were not observed on the soil, presumably because their growths are restricted by the presence of the great amount of litter (leaves, stems and other organic residues) on the forest ground.

Thus, in each 1 ha plot, 30 trees were sampled for the presence of visible growths of algae or bryophytes, which were gathered with penknife and kept in paper bags.

Algal masses collected were first examined under stereoscopic microscope and latter under light microscope with image capture system. The study of the organisms was conducted according to the usual techniques and the classification system adopted was that of Graham \& Wilcox (2000).

In this study we focused the main components of the algal communities and those species with occasional occurrence and very low densities were not considered. As

Table 1. Localization and total area of the forest remnants studied.

\begin{tabular}{llccr}
\hline Remnant & Municipality & $\begin{array}{c}\text { Latitude } \\
\text { (S) }\end{array}$ & $\begin{array}{c}\text { Longitude } \\
\text { (W) }\end{array}$ & $\begin{array}{r}\text { Area } \\
\text { (ha) }\end{array}$ \\
\hline A1 & Novo Horizonte & $21^{\circ} 31^{\prime} 15^{\prime \prime}$ & $49^{\circ} 17^{\prime} 41^{\prime \prime}$ & 635.0 \\
A2 & Sales & $21^{\circ} 24^{\prime} 17^{\prime \prime}$ & $49^{\circ} 30^{\prime} 01^{\prime \prime}$ & $1,799.6$ \\
A3 & Planalto & $21^{\circ} 00^{\prime} 05^{\prime \prime}$ & $49^{\circ} 58^{\prime} 26^{\prime \prime}$ & 207.5 \\
A4 & União Paulista & $20^{\circ} 55^{\prime} 16^{\prime \prime}$ & $49^{\circ} 55^{\prime} 34^{\prime \prime}$ & 230.4 \\
A5 & São João da Iracema & $20^{\circ} 28^{\prime} 25^{\prime \prime}$ & $50^{\circ} 17^{\prime} 36^{\prime \prime}$ & $1,656.2$ \\
A6 & Matão & $21^{\circ} 37^{\prime} 14^{\prime \prime}$ & $48^{\circ} 32^{\prime} 14^{\prime \prime}$ & $2,189.6$ \\
A7 & Vicentópolis & $20^{\circ} 55^{\prime} 34^{\prime \prime}$ & $50^{\circ} 20^{\prime} 55^{\prime \prime}$ & 128.2 \\
A8 & Ida Iolanda & $20^{\circ} 44^{\prime} 34^{\prime \prime}$ & $49^{\circ} 55^{\prime} 45^{\prime \prime}$ & 66.8 \\
A9 & Votuporanga & $20^{\circ} 30^{\prime} 52^{\prime \prime}$ & $50^{\circ} 05^{\prime} 12^{\prime \prime}$ & 112.6 \\
A10 & Turmalina & $20^{\circ} 00^{\prime} 13^{\prime \prime}$ & $50^{\circ} 26^{\prime} 02^{\prime \prime}$ & 108.3 \\
\hline
\end{tabular}




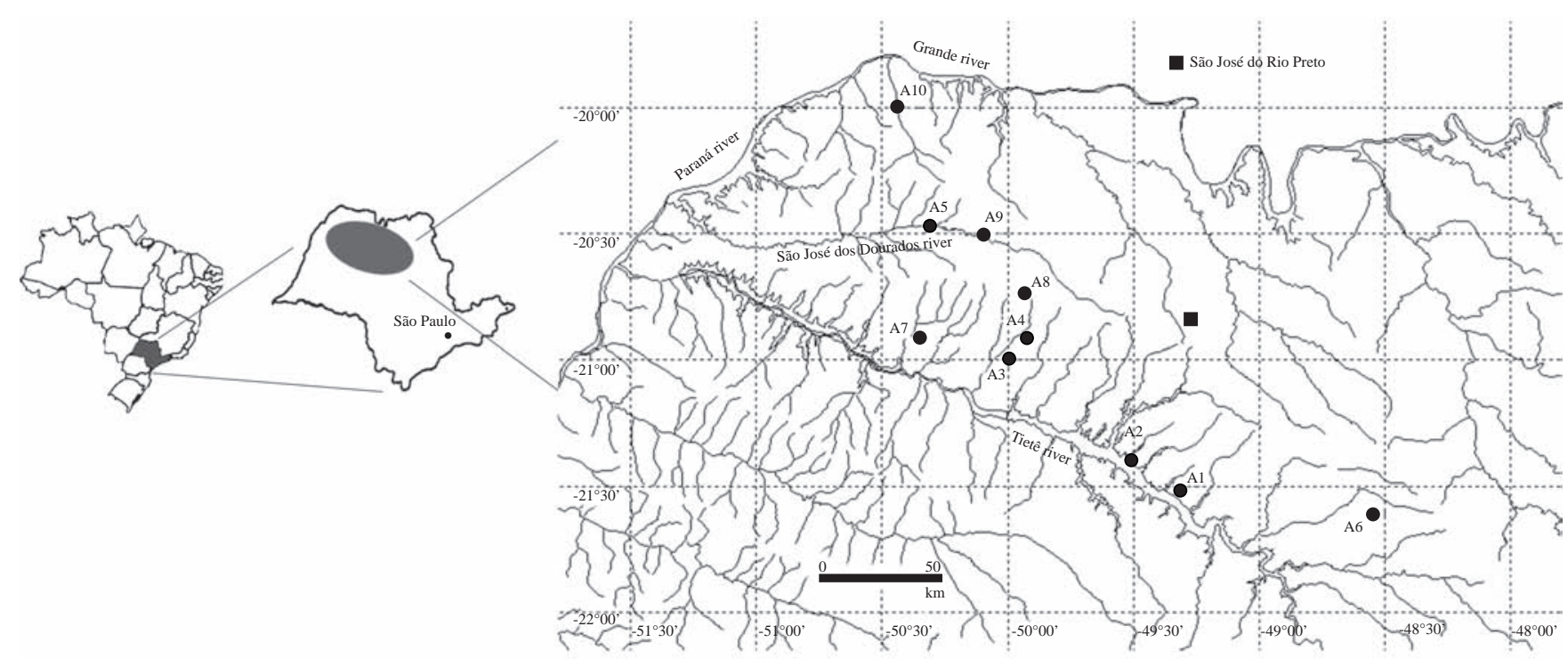

Figure 1. Schematic map of the northwest region of São Paulo State showing the distribution of the ten studied remnants.

it is the very first comprehensive account of the aerophytic flora, the identification of rare organisms can be inaccurate and problematic.

At least 20 observations of each qualitative or quantitative taxonomic characteristic were made for each population/ species found.

The following information is presented for each species: a taxonomic description according to the standard patterns for the respective group, photomicrographs, distribution in the studied fragments and pertinent taxonomic comments. Representative specimens of each species were deposited in SJRP herbarium (Ibilce/UNESP - São José do Rio Preto) and the record number is also presented together with species distribution. The abbreviations diam. and L/D found in the descriptions correspond to cell diameter and cell length/ diameter ratio, respectively.

\section{Results}

The survey resulted in nine species of green algae, distributed through the classes Trebouxiophyceae (one species), Charophyceae (one species) and Ulvophyceae (seven species).

Trebouxiophyceae

Desmococcus olivaceus (Persoon ex Archerson) J. R. Laundon, Taxon 34: 671, 1985.

Figures 2-4

Cells single or 2 to 4-celled colonies; cells spherical (when isolate), hemispherical or irregular, 4.0-8.0 $\mu \mathrm{m}$ diam.; chloroplast parietal, pyrenoid not observed; aplanosporangia spherical with ornamented wall.
Occurrence: A2 (SJRP 28292), A4 (SJRP 29635), A5 (SJRP 29645) and A9 (SJRP 28267).

According to Ettl \& Gärtner (1995), D. olivaceus can be found in a sort of substrates (corticolous, edaphic, epilithic). Vischer (1960) noted that, in natural conditions, the sarcinoid stages are dominant, while filaments are more frequent in cultures and the author statement was corroborated by Rifón-Lastra \& Noguerol-Seoane (2000) and Rindi \& Guiry (2003). In this study, only sarcinoid forms were observed.

The species is considered as cosmopolitan, as has been reported in Bangladesh by Nurul-Islam (1972), in Ireland by Schlichting (1975) and Rindi \& Guiry (2003), in Antarctica by Broady \& Ingerfeld (1993) and in Iberian Peninsula by Leitão et al. (1996), NoguerolSeoane \& Rifón-Lastra (1997) and Rifón-Lastra \& Noguerol-Seoane (2000).

This is the first record of the species for Brazilian territory.

Charophyceae

Klebsormidium crenulatum (Kützing) Lokhorst, J. Phycol. 21: 474, 1985.

Figures 5-6

Plant mass of entangled filaments, green; filaments prostrated, strongly attached to the substrate, short, with up to 35 cells, not or slightly constricted, $11.0-14.0 \mu \mathrm{m}$ diam.; cells (5.0-)8.0-10.0(-12.0) $\mu \mathrm{m}$ long, D/L 0.5 to 1.0; chloroplast parietal, 1 pyrenoid per cell.

Occurrence: A4 (SJRP 29627) and A8 (SJRP 28270). 
Klebsormidium is one of the commonest genera of terrestrial Chlorophyta (López-Bautista et al. 2007). The metric characteristics (mainly isodiametric or short cells and thick cell walls) of the studied populations are accordingly to those presented by Ettl \& Gärtner (1995) and Lokhorst (1996) for K. crenulatum. Regarding to species ecology, several papers record $K$. crenulatum to aerophytic environment, including barks (Freystein et al. 2008), historic monuments (Uher et al. 2005) and soil (Lukešová 2001). Sluiman et al. (2008) consider that many morphological characteristics used in Klebsormidium taxonomy are homoplastic and, therefore, unsatisfactory to species distinction and recommend the additional use of molecular tools.
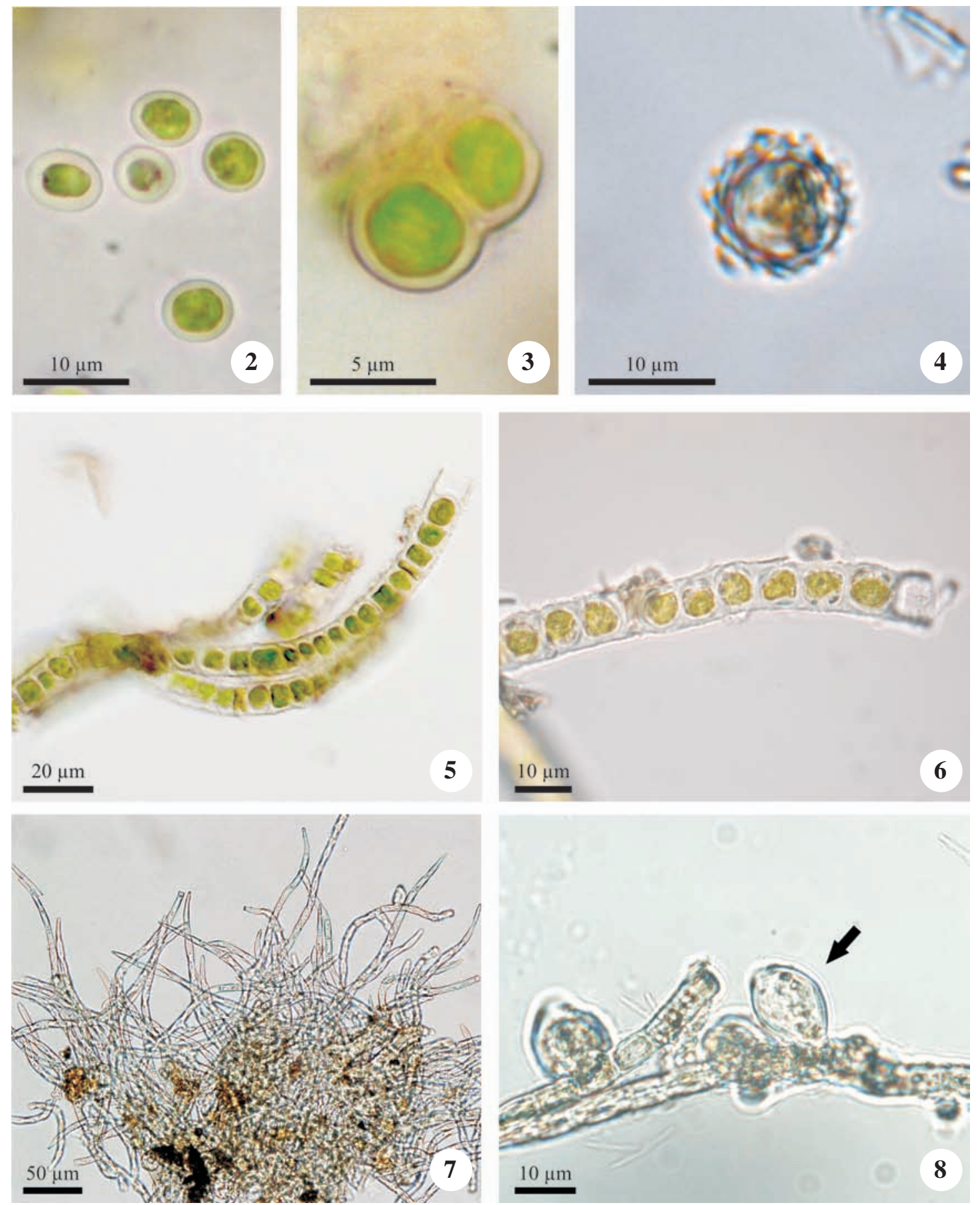

Figures 2-8. 2-4. Desmococcus olivaceus. 4. Aplanosporangium. 5-6. Klebsormidium flaccidum. 7-8. Printzina effusa. 8. Presumptive gametangium (arrow). 


\section{Ulvophyceae}

Printzina effusa (Krempelhüber) Thompson \& Wujek, J. Phycol. 28: 235, 1992.

Figures 7-8

Plant mass of erect filaments, green; filaments branched, not constricted, tapered towards the apex, 5.0-8.0 $\mu \mathrm{m}$ diam.; cells cylindrical, 8.0-10.0(-12.0) $\mu \mathrm{m}$ long, D/L (1.0-)1.3 to 1.7(-2.0); apical cell acute, arrow-shaped; presumptive gametangia lateral or at the branching basis, sometimes in pairs, oval, with a ostiole at the top, $12.0-14.0 \mu \mathrm{m}$ diam., $16.0-22.0 \mu \mathrm{m}$ long; zoosporangia not observed.

Occurrence: A4 (SJRP 28269) and A6 (SJRP 29633).

The study populations have metrics and reproductive structures similar to those of the Trentepohlia effusa described by Cribb $(1963,1989)$ and of the Printzina effusa described by Thompson \& Wujek (1992), differing from the last by the longer cell dimensions (20.0-28.0 $\mu \mathrm{m})$. Rindi et al. (2005) found the gametophytic and sporophytic generations of $P$. effusa, where the gametophytic thallus is also compatible to the specimens studied and characterized by the higher cell length/diameter ratio (twice to five times longer than wide). Printzina effusa was also found by Rindi \& López-Bautista (2008) in tropical rainforests of French Guiana, with great L/D ratio (seven to eight times longer than wide).

The genus Printzina, proposed by Thompson \& Wujek (1992), was separated from Trentepohlia due to the presence of globular to reniform sporangia and the occurrence of a well-developed prostrate system, clearly distinguishable of the erect portion, in contrast to the oval sporangia and a less developed prostrate system found in Trentepohlia. According to Rindi \& LópezBautista (2007), the validity of the genera separation is doubtful because the distinctive characteristics are not well-defined and there is no evident distinction between prostrate and erect systems in the type species Printzina lagenifera (Hildebrand) R. H. Thompson \& D. E. Wujek. In addition, recent molecular evidences from SSU rDNA sequences do not support such separation (López-Bautista et al. 2006). However, many modern studies (e.g. Rindi \& López-Bautista 2008) still include some species under Printzina.

Most studies still consider the validity of Printzina, despite the uncertainties (and even the first molecular evidences) about the existence of the both genera separately; it is highly probable that the two genera have to be merged. However, the general view is that more comprehensive studies including a higher number of species from different localities, mainly supported by molecular markers, are required to a reappraisal of the entire order; any taxonomic proposition at this point can be inaccurate and incomplete. Thus, the usual decision of maintenance of the genus Printzina is followed in the present work.

This is the first record of the genus and species in the Brazilian territory.

\section{Trentepohlia}

Key for identification of found Trentepohlia species

1. Filaments up to $12.0 \mu \mathrm{m}$ diam.

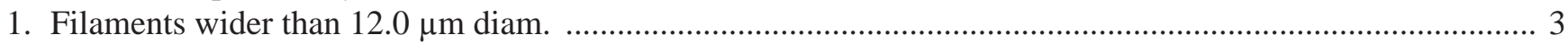

2. Filaments up to $9.0 \mu \mathrm{m}$ diam. T. abietina

2. Filaments wider than $9.0 \mu \mathrm{m}$ diam. T. $c f$. dusenii

3. Filaments constricted, elliptical or moniliform cells T. monilia

3. Filaments not constricted, cylindrical cells T. diffracta

4. Inconspicuous masses, cells usually shorter than $20.0 \mu \mathrm{m}$ long

4. Cottony masses, cells usually longer than $20.0 \mu \mathrm{m}$ long 5

5. Filaments tapered, conical apical cells, zoosporangia in groups T. arborum

5. Filaments not tapered, round apical cells, isolated zoosporangia T. aurea

Trentepohlia abietina (Flotow) Hansgirg, Prodr. Alg. Bǒhmen 1: 86, 1886.

Figures 9-10

Plant mass cottony, formed by entangled filaments, orange; filaments branched, cylindrical, not constricted,
6.7-8.3 $\mu \mathrm{m}$ diam.; cells cylindrical, 15.0-21.7 $\mu \mathrm{m}$ long, D/ L 1.8 to 3.5; apical cell rounded; presumptive gametangia rounded or oval, apical or lateral, single, $18.1-25.0 \mu \mathrm{m}$ diam., 15.0-25.0 $\mu \mathrm{m}$ long; zoosporangia not observed.

Occurrence: A4 (SJRP 29628), A7 (SJRP 29694) and A10 (SJRP 28266). 
Following previous works (e.g., Rindi et al. 2005), the reproductive structure found in the populations is named "presumptive gametangium" because biflagellate gametes were not observed, although its morphology and position are compatible to those of a gametangium.

Ettl \& Gärtner (1995) described T. abietina with cylindrical cells, 4.0-10.0 $\mu \mathrm{m}$ diam., D/L 1 to 3 times longer than wide and lateral or apical gametangia. Cribb (1958) found the species in tropical forests of Australia with similar morphological and metric characteristics to the Brazilian populations; however the author described the occurrence of a thickened wall in the apical cell that is not typical for the species.

Trentepohlia abietina is one of the most widespread species of the genus and has been found in urban environments of occidental region of Ireland (Rindi \& Guiry 2002), Hawaiian Islands (Rindi et al. 2005), Africa (Rindi et al. 2006), French Guiana (Rindi \& López-Bautista 2008) and several other tropical and temperate regions of the world (De Wildeman 1900, Jose \& Chowdary 1980, Tracanna 1989, Ettl \& Gärtner 1995, John 2002). The species is also recorded growing on spider cephalothoraxes (Cribb 1964). In Brazil, the species occurrence was firstly reported by Akiyama (1971).

Trentepohlia arborum (Agardh) Hariot, J. Bot. 3: 383, 1889.

Figures 11-12

Plant mass cottony, formed by entangled filaments, green; filaments branched, erect, tapered to the apex, not constricted, 14.0-30.0 $\mu \mathrm{m}$ diam.; branches at $90^{\circ}$ angle; cells cylindrical, 22.0-60.0(-70.0) $\mu \mathrm{m}$ long, D/ L 0.9-2.5; apical cell acute; gametangia not observed; zoosporangia round, lateral or apical, in groups of 5 to 8, (14.0-)16.0-20.0 $\mu \mathrm{m}$ diam.

Occurrence: A1 (SJRP 28278), A2 (SJRP 28293), A3 (SJRP 28297), A4 (SJRP 29629), A6 (SJRP 28264) and A7 (SJRP 29656).

Trentepohlia arborum is characterized by the formation of grouped sporangia from a basal swelled cell (suffultory cell) and the tapered filament (Cribb 1958).

Most specimens studied were pre-lichenized and some morphological changes could be occurred, but no differences between prostrate and erect system were observed, corroborating the data by Rindi et al. (2005) and Akiyama (1971). However, Ettl \& Gärtner (1995) and Bicudo \& Santos (2001) found significant differences between the two systems. Cribb $(1987,1989)$ recorded narrower T. arborum filaments than those observed in the populations studied $(10.0-22.5 \mu \mathrm{m}, 5.0-15.5 \mu \mathrm{m}$, respectively).

Rindi \& López-Bautista (2008) reported the occurrence of T. arborum in several types of natural and artificial substrates in French Guiana and commented it is one of the constituents of the common lichen Coenogonium.

Trentepohlia aurea (Linnaeus) Martius, Sumptibus J. L. Schrag 1: 351, 1817.

Figures 13-14

Plant mass cottony, formed by entangled filaments, green; filaments richly branched, erect, not tapered to the apex, not constricted, (12.0-)14.0-16.0(-20.0) $\mu \mathrm{m}$ diam.; lateral branches with cylindrical or barrel-shaped cells; cells cylindrical, (10.0-)26.0-28.0(-44.0) $\mu \mathrm{m}$ long, D/L 1.6-2.5; apical cell rounded; gametangia not observed; zoosporangia oval, usually in lateral branches, single, 22.0-26.0 $\mu \mathrm{m}$ diam., 16.0-24.0 $\mu \mathrm{m}$ long.

Occurrence: A1 (SJRP 28279) and A3 (SJRP 28265).

The populations examined are compatible with those described by Ettl \& Gärtner (1995) for filament diameter and D/L ratio (10.0-24.0 $\mu \mathrm{m}$ diam., cells 1.5 to 3.0 times longer than wide); the authors described the occurrence of richly branched filaments and single sporangia. The filament diameter $(10.0-22.0 \mu \mathrm{m})$ reported by Cribb (1958) is similar to the specimens analyzed, however their cells are longer (2 to 4 times) than those observed in the present study and the sporangia are sessile.

Morphometric data for Brazilian populations of $T$. aurea described by Akiyama (1971) are close to the presently studied specimens; the author reported two unnamed reproductive structures: one sessile, probably corresponding to the gametangium, and another pedicellate and isolate, probably corresponding to the sporangium. Bicudo \& Santos (2001), for São Paulo State, and Rindi \& López-Bautista (2008), for French Guiana, also described $T$. aurea with similar shape and size to the Brazilian specimens.

Trentepohlia diffracta (Krempelhüber) Hariot, J. Bot. 3: 396, 1889.

Figures 15-16

Isolated filaments or few entangled forming smalls groups; filaments richly branched, prostrate, cylindrical, not constricted, 14.0-16.0(-18.0) $\mu \mathrm{m}$ diam.; branches usually at $90^{\circ}$ angle; cells cylindrical, (14.0-)16.0- 

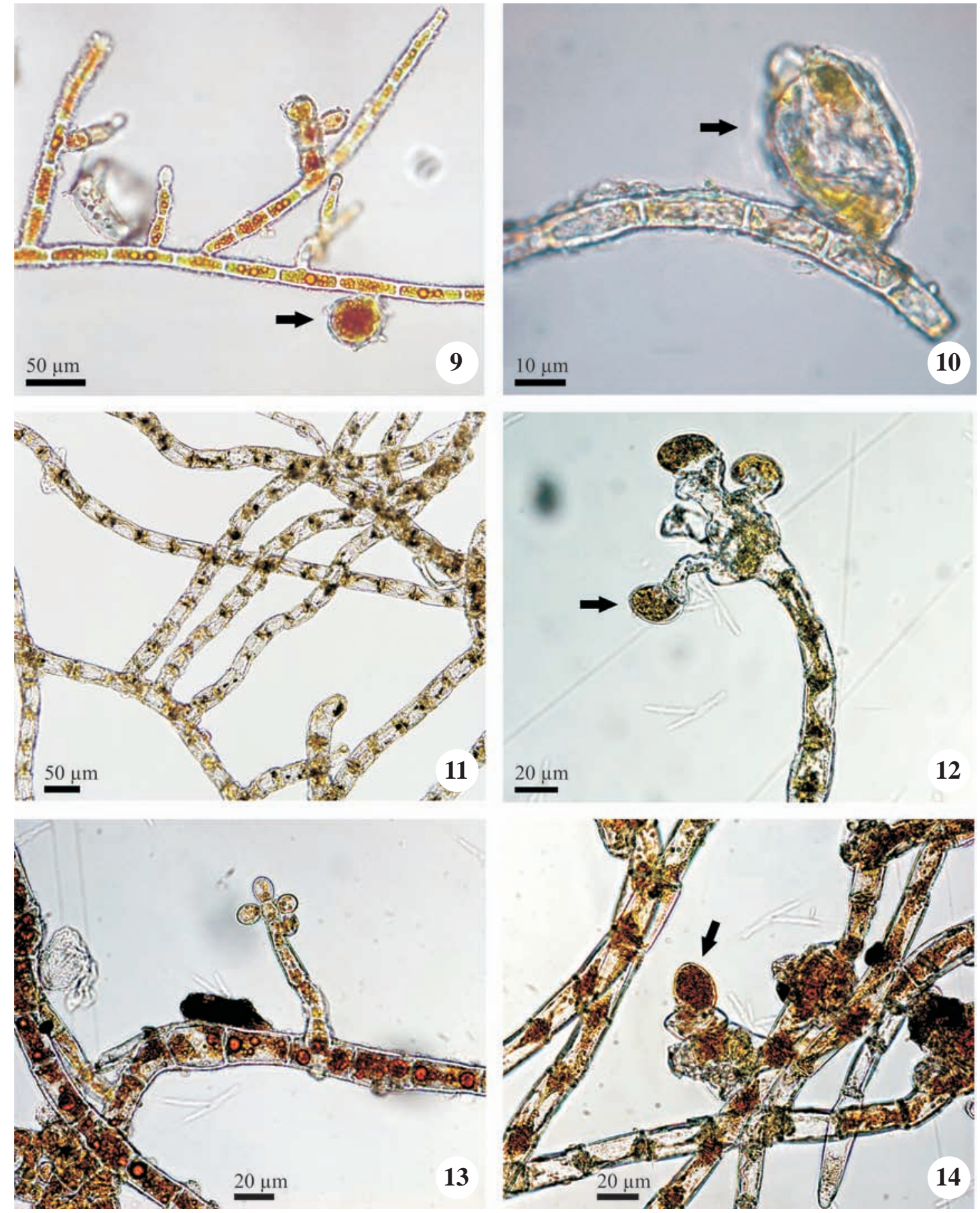

Figures 9-14. 9-10. Trentepohlia abietina. Presumptive gametangium (arrows). 11-12. T. arborum. 12. Zoosporangium (arrow). 13-14. T. aurea. 14. Zoosporangium (arrow).

18.0(-24.0) $\mu \mathrm{m}$ long, D/L 0.7 to 1.1(-1.7); apical cell slightly narrowed to the apex; reproductive structures not observed.

Occurrence: A1 (SJRP 28280), A2 (SJRP 28294), A4 (SJRP 29630), A5 (SJRP 29637), A6 (SJRP 29652), A8 (SJRP 29666), A9 (SJRP 28267) and A10 (SJRP 29695).
Trentepohlia diffracta growth is distinct from the other species of the genus because isolated filaments occur interwoven with bryophytes and not form conspicuous masses. Beside the type-variety, the species also comprises the var. colorata described by Cribb (1968) on the basis of specimens from tropical forests of Australia, differing from the type-variety by its 
smaller cell diameter (11.5-15.5 $\mu \mathrm{m}$ and 17.0-21.5 $\mu \mathrm{m}$, respectively).

The type variety was reported for Brazil by Akiyama (1971) with smaller cell dimensions (10.0-16.0 $\mu \mathrm{m}$ diam. and 12.5-20.0 $\mu \mathrm{m}$ long), short filaments and with no distinction between main filament and branches.
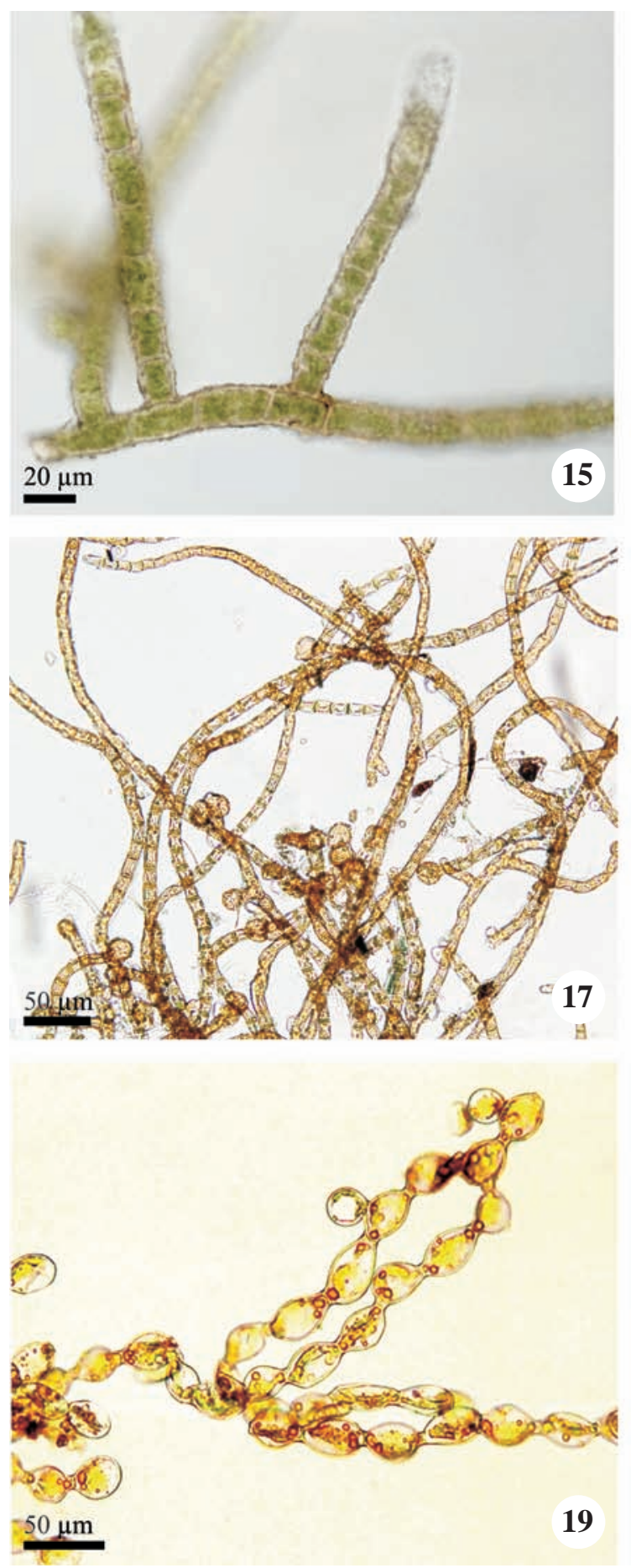

Trentepohlia cf. dusenii (Wittrock \& Nordstedt) Hariot, Botaniska Notiser 185: 200, 1893.

Figures 17-18

Plant mass cottony, formed by entangled filaments, orange; filaments branched, cylindrical or slightly tapered,
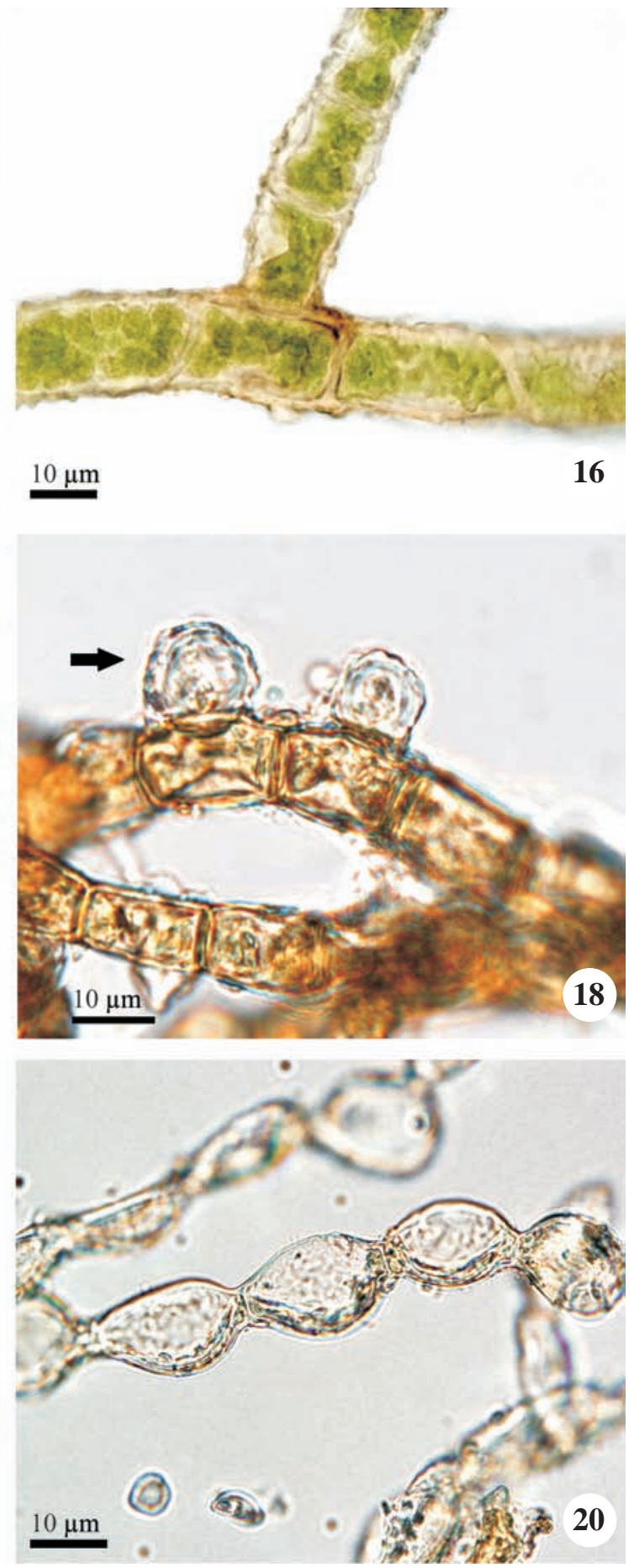

Figures 15-20. 15-16. Trentepohlia diffracta. 17-18. T. cf. dusenii. 18. Presumptive gametangium (arrow). 19-20. T. monilia. 
not constricted, 9.6-12.0 $\mu \mathrm{m}$ diam.; branches at $90^{\circ}$ angle; cells cylindrical, (13.6-)15.2-16.0 $\mu \mathrm{m}$ long, D/L 1.3 to 1.8, cell wall reddish; apical cell rounded; presumptive gametangia rounded, apical or lateral, single or in pairs, 9.6-12.0 $\mu \mathrm{m}$ diam.; zoosporangia not observed.

Occurrence: A1 (SJRP 29632) and A4 (SJRP 28263).

Rindi \& López-Bautista (2007) comment that Trentepohlia dusenii is one of the least-known species of the genus and its characterization is difficult by the scarcity of descriptions and illustrations.

In the study material, only the gametophytic phase was found and the general filament morphology and reproductive structures are compatible to those presented by Cribb (1963) and Rindi \& López-Bautista (2007). However, the cell dimensions of the Brazilian specimens were larger than the data provided by Cribb (1963) (6.0-11.0 $\mu \mathrm{m}$ long and 5.0-7.0 $\mu \mathrm{m}$ diam.) and Rindi \& López-Baustista (2007) (4.5-7.5 $\mu \mathrm{m}$ diam. and 1 to 4 times longer than wide). In addition, it was not observed distinction between the prostrate and erect systems, as recorded by other authors.

Thus, despite there is good correspondence between morphological characters of the populations studied with literature data, there are also some important metric divergences.

Trentepohlia dusenii was found growing on palm tree leaves in Australia (Cribb 1963) and on a post in French Guiana (Rindi \& López-Bautista 2007). Jose \& Chowdary (1980) also reported the species in Calcutta, India.

If the identity of the populations is confirmed, this is the first record of the species for Brazil.

Trentepohlia monilia De Wildemann, Bull. Soc. R. Bot. Belg. 27: 181, 1889.

Figures 19-20

Plant mass cottony, formed by entangled filaments, green to orange; filaments short, richly branched, deeply constricted, 20.0-34.0 $\mu \mathrm{m}$ diam.; cells elliptical to barrel-shaped, (22.0-)26.0-42.0 $\mu \mathrm{m}$ long, D/L 0.8 to 1.5; reproductive structures not observed.

Occurrence: A1 (SJRP 28281), A2 (SJRP 28295), A3 (SJRP 28299), A4 (SJRP 29631), A5 (SJRP 29636), A7 (SJRP 29657), A8 (SJRP 28268), A9 (SJRP 29686) and A10 (SJRP 29696).

In 1920, Printz transferred this species to the new genus Physolinum, on the basis of the thallus form, the argued presence of aplanospores and the distinct type of cell division. Later, Flint (1959) observed the zoospore production instead aplanospore formation in Physolinum monilia and proposed the return of the species to Trentepohlia.

The uncertainties about the real position of the species cause the possibility for use of both names and some authors, as Davis et al. (1989), Davis \& Rands (1993) and Bicudo \& Santos (2001), refer to the species as Physolinum monilia, while others, as Akiyama (1971) and Ettl \& Gärtner (1995), use the name Trentepohlia monilia.

\section{Discussion}

The aerophytic green algal flora found is not considerably different from those of other regions, once several species and genera found during this survey have been also reported in previous studies on aerophytic green algae in different world regions.

Neustupa \& Škaloud (2008), in a similar study about the cyanobacterial and algal diversity found on tree barks in an Indonesian tropical forest, found 20 species of green algae, being six Trentepohliales and 14 coccal green algae; most of them were (mainly coccal green algae) observed only after culturing.

Some taxa recorded in the present study were also found in taxonomic surveys conducted in distinct aerophytic habitats, as walls and soils. Rindi \& Guiry (2003) reported 27 aerophytic green algae in urban environments of Ireland and three of them (Desmococcus olivaceus, Trentepohlia abietina and T. aurea) were also found in this study. Desmococcus olivaceus and the genus Klebsormidium were observed in biofilms on sandstone outcrops in Luxembourg by Hoffmann \& Darienko (2005), besides another 38 species of green algae. Flechtner et al. (1998) observed 36 green algae growing in microbiotic crusts in Mexico.

In comparison with the studies on the Brazilian Trentepohliales, three species (Trentepohlia abietina, T. arborum and T. monilia) are shared with Akiyama (1971) and two species (T. arborum and T. monilia, as Physolinum monilia), with Bicudo \& Santos (2001).

The results show that the green algal communities were mainly represented by members of Trentepohliales in the studied environments. The successful establishment of the Trentepohliales in such restrictive environments, like epiphytic habitat, can be the product of adaptations as the presence of sporopollenin-like compounds in the cell wall (Good \& Chapman 1978) and a special carbohydrate and alcohol pattern (Feige \& Kremer 1980, Patterson \& Van Valkenburg 1991) that probably reflect adaptative characters against the dehydration in aerial 
habitats. In addition, protective mechanisms to avoid excessive irradiance, as carotenoids production (Prescott 1984) and thallus form, constitute important strategies to deal with the terrestrial environment.

In this paper, the taxonomic identification of Trentepohliales members was based on morphological and ecological features, similarly to other surveys carried out in tropical regions (e.g. Rindi \& López-Bautista 2008, Rindi et al. 2008). Due to the scarcity of studies on these organisms in the tropical regions and especially in Brazilian territory, these records can be considered important to the knowledge about the morphological diversity and geographical distribution of the group. However, classical taxonomy of Trentepohlia species has been considered problematic and molecular data have played important role (Rindi et al. 2009) and more detailed studies are needed.

Although the total area surveyed is relatively restricted in comparison with the country area and also considering that just one ecosystem was studied, the present results highlight the need of the improvement of floristic and ecological investigations on aerophytic flora. This necessity can be properly exemplified by the finding of Desmococcus olivaceus, which is considered the commonest terrestrial alga in the world (Laundon 1985, Ettl \& Gärtner 1995) and it has been reported for the first time for Brazilian territory only in this paper.

It is strongly recommended the increment of research projects on such communities, including approaches focusing on other habitats (as the epiphyllic, for instance) and ecosystems, to provide some elementary knowledge about this important group of primary producers.

Acknowledgements - Authors are indebted to Fapesp (2007/01667-8) for the fellowship to N.M.L.S. and financial support through the project "Fauna and flora from forest fragments in the northwest region of São Paulo State: the basis to biodiversity conservational studies" (2004/04820-3); to CNPq grants to L.H.Z.B. (307243/2006-0) and to O.N.J. (305153/2006-4). We are also grateful to Jeferson Luizi Pereira, Marcos Vinícius Bernardino and Vinícius Agostini Machado, for help during field works.

\section{References}

AKIYAMA, M. 1971. On some Brazilian species of Trentepohliaceae. Memoirs of the Faculty of Education Shimane University. Natural Sciences 5:81-95.

BICUDO, C.E.M. \& SANTOS, C.I. 2001. Criptógamos do Parque Estadual das Fontes do Ipiranga, São Paulo, SP. Algas, 15: Chlorophyceae (Trentepohliales). Hoehnea 28:183-190.
BROADY, P.A. \& INGERFELD, M. 1993. Three new species and a new record of Chaetophoracean (Chlorophyta) algae from terrestrial habitats in Antartica. European Journal of Phycology 28:25-31.

CRIBB, A.B. 1958. The genus Trentepohlia in South-Eastern Queensland. University of Queensland Department of Biology Papers 3:193-201.

CRIBB, A.B. 1963. Further records of Trentepohlia from South-Eastern Queensland. University of Queensland Department of Biology Papers 4:73-84.

CRIBB, A.B. 1964. Notes on Trentepohlia from Queensland including one growing on a spider. University of Queensland Department of Biology Papers 4:99-108.

CRIBB, A.B. 1968. Some Trentepohlias new to Australia. Phykos 7:3-8.

CRIBB, A.B. 1987. Some species of Trentepohlia from Java and Bali. Queensland Naturalist 27:31-33.

CRIBB, A.B. 1989. The algal genus Trentepohlia in Tasmania. Queensland Naturalist 29:3-6.

CRISPIM, C.A., GAYLARDE, P.M. \& GAYLARDE, C.C. 2003. Algal and cyanobacterial biofilms on calcareous historic buildings. Current Microbiology 46:79-82.

DAVIS, J.S. \& RANDS, D.G. 1993. Observations on lichenized and free-living Physolinum (Chlorophyta, Trentepohliaceae). Journal of Phycology 29:819-825.

DAVIS, J.S., RANDS, D.G. \& LACHAPELLE, M. 1989. Heavily lichenized Physolinum (Chlorophyta) from a dimly lit cave in Missouri. Journal of Phycology 25:419-428.

DE WILDEMAN, E. 1900. Les algues de la flore de Buitenzorg (Essai d'une flore algologique de Java). E. G. Brill, Leiden.

ETTL, H. \& GÄRTNER, G. 1995. Syllabus der Boden-, Luft- and Flechtenalgen. Gustav Fischer Verlag, Jena and New York.

EVANS, R.D. \& JOHANSEN, J.R. 1999. Microbiotic crusts and ecosystem processes. Critical Reviews and Plants Sciences 18:183-225.

FEIGE, G.B. \& KREMER, B.P. 1980. Unusual carbohydrate pattern in Trentepohlia species. Phytochemistry 19:18441845.

FLECHTNER, V.R., JEFFREY, J.R. \& CLARK, W.H. 1998. Algal composition of the microbiotic crusts from the Central Desert of Baja California, Mexico. The Great Basin Naturalist 54:295-311.

FLINT, E.A. 1959. The occurrence of zoospores in Physolinum Printz. New Phytologist 58:267-270.

FREYSTEIN, K., SALISCH, M. \& REISSER, W. 2008. Algal biofilms on tree bark to monitor airborne pollutants. Biologia 63:866-872.

FRITSCH, F.E. 1907. A general consideration of the subaerial and freshwater algal flora of Ceylon. Proceedings of Royal Society 79:197-254.

GAYLARDE, P.M. \& GAYLARDE, C.C. 1999. Algae and cyanobacteria on painted buildings in Latin America. International Biodeterioration \& Biodegradation 46:93-97. 
GOOD, B.H. \& CHAPMAN, R.L. 1978. The ultrastructure of Phycopeltis (Chroolepidaceae, Chlorophyta). I. Sporopollein in the cell walls. American Journal of Botany 65:27-33.

GRAHAM, L.E. \& WILCOX, L.W. 2000. Algae. Prentice Hall, Upper Saddle River.

HOFFMANN, L. 1989. Algae of terrestrial habitats. The Botanical Review 55:77-105.

HOFFMANN, L. \& DARIENKO, T. 2005. Algal biodiversity on sandstone in Luxemburg. Ferrantia 44:99-102.

HU, C., LIU, Y., SONG, L. \& ZHANG, D. 2002. Effect of desert soil algae on the stabilization of fine sands. Journal of Applied Phycology 14:281-292.

ISLAM, N. 1960. Some subaerial green algae from East Pakistan. Transactions of the American Microscopical Society 79:471-479.

JOHN, D.M. 2002. Order Trentepohliales. In The freshwater algal flora of the British Isles (D.M. John, B.A. Whitton \& A.J. Brook, eds.). Cambridge University Press, Cambridge, p.475-479.

JOSE, G. \& CHOWDARY, Y.B.K. 1980. New records of Trentepohlia from India. Nova Hedwigia 32:725-731.

LAUNDON, J. 1985. Desmococcus olivaceus - the name of the common subaerial green algae. Taxon 34: 671-672.

LEITÃO, M.T., SANTOS, M.F., SÉRGIO, C., ORMONDE, J. \& CARVALHO, G. 1996. Plantas criptogamas na atmosfera de Coimbra, Portugal. Anales del Jardín Botánico de Madrid 54:31-36.

LEWIS, L.A. \& McCOURT, R.M. 2004. Green algae and the origin of land plants. American Journal of Botany 91:1535-1556.

LOKHORST, G.M. 1996. Comparative taxonomic studies on the genus Klebsormidium (Charophyceae) in Europe. Gustav Fischer Verlag, New York.

LÓPEZ-BAUTISTA, J.M., WATERS, D.A. \& CHAPMAN, R.L. 2002. The Trentepohliales revised. Constancea 83.1. http://bama.ua.edu/ jlopez/Trenterevisited.pdf (accessed in 2009).

LÓPEZ-BAUTISTA, J.M., RINDI, F. \& GUIRY, M.D. 2006. Molecular systematics of the subaerial green algal order Trentepohliales: an assessment based on morphological and molecular data. International Journal of Systematic and Evolutionary Microbiology 56:17091715.

LÓPEZ-BAUTISTA, J.M., RINDI, F. \& CASAMATA, A.D. 2007. The systematics of subaerial algae. In Cell origin, life in extreme habitats and Astrobiology. Algae and Cyanobacteria in extreme environments (J. Sechbach, ed.). Springer, Netherlands, p.601-617.

LUKEŠOVÁ, A. 2001. Soil algae in brown coal and lignite post-mining areas in Central Europe (Czech Republic and Germany). Restoration Ecology 9:341-350.

METTING, B. 1981. The systematics and ecology of soil algae. The Botanical Review 47:195-312.
NAKANO, T., HANDA, S. \& TAKESHITA, S. 1991. Some corticolous algae from the Taishaku-Kyo Gorge, Western Japan. Nova Hedwigia 52:427-451.

NEUSTUPA, J. \& ŠKALOUD, P. 2008. Diversity of subaerial algae and cyanobacteria on tree bark in tropical mountain habitats. Biologia 63:806-812.

NOGUEROL-SEOANE, A. \& RIFÓN-LASTRA, A. 1997. Epilithic phycoflora on monuments: a survey of Esteban de Ribas de Sil Monastery (Ourense NW Spain). Cryptogamie, Algologie 18:351-361.

NURUL-ISLAM, A.K.M. 1972. Subaerial algae of Bangladesh. Bangladesh Journal of Botany 1:13-64.

ORTEGA-CALVO, J.J., HERNANDEZ-MARINE, M. \& SAIZ-JIMENEZ, C. 1991. Biodeterioration of building material by cyanobacteria and algae. International Biodeterioration \& Biodegradation 28:165-185.

PATTERSON, G.W. \& VAN VALKENBURG, S. 1991. Sterols of Cephaleuros (Trentepohliaceae), a parasitic green alga. Journal of Phycology 27:549-551.

PRESCOTT, G.W. 1984. The algae: a review. Oto Koeltz Science, Koenigstein.

PRINTZ, H. 1920. Subaerial algae from South Africa. Kongelige Norske Videnskabers Selskab Skrifter 1: 3-41.

RIFÓN-LASTRA, A. \& NOGUEROL-SEOANE, A. 2000. Algunas Chaetophorales subaéreas interesantes para la Peninsula Ibérica. Portugaliae Acta Biologica 19:81-89.

RINDI, F. \& GUIRY, M.D. 2002. Diversity, life history and ecology of Trentepohlia and Printzina (Trentepohliales, Chlorophyta) in urban habitats in Western Ireland. Journal of Phycology 38:39-54.

RINDI, F. \& GUIRY, M.D. 2003. Composition and distribution of subaerial algal assemblages in Galway City, western Ireland. Cryptogamie, Algologie 24:245-267.

RINDI, F., GUIRY, M.D. \& LÓPEZ-BAUTISTA, J.M. 2006. New records of Trentepohliales (Ulvophyceae, Chlorophyta) from Africa. Nova Hedwigia 83:431449.

RINDI, F., LAM, D.W. \& LÓPEZ-BAUTISTA, J.M. 2008. Trentepohliales (Ulvophyceae, Chlorophyta) from Panama. Nova Hedwigia 87:421-444.

RINDI, F., LAM, D.W. \& LÓPEZ-BAUTISTA, J.M. 2009. Phylogenetic relationships and species circumscription in Trentepohlia and Printzina (Trentepohliales, Chlorophyta). Molecular Phylogenetics and Evolution 52:329-339.

RINDI, F. \& LÓPEZ-BAUTISTA, J.M. 2007. New and interesting records of Trentepohlia (Trentepohliales, Chlorophyta) from French Guiana, including the description of two new species. Phycologia 46:698-708.

RINDI, F. \& LÓPEZ-BAUTISTA, J.M. 2008. Diversity and ecology of Trentepohliaceae (Trentepohliales, Chlorophyta) in French Guiana. Cryptogamie, Algologie 29:13-43. 
RINDI, F., SHERWOOD, A.R. \& GUIRY, M.D. 2005. Taxonomy and distribution of Trentepohlia and Printzina (Trentepohliales, Chlorophyta) in the Hawaiian Islands. Phycologia 44:270-284.

SCHLICHTING JR., H.E. 1975. Some subaerial algae from Ireland. British Phycological Journal 10:257-261.

STARKS, L.T., SHUBERT, L.E. \& TRAINOR, F.R. 1981. Ecology of soil algae: a review. Phycology 20:65-80.

SLUIMAN, H.J., GUIHAL, C. \& MUDIMU, O. 2008. Assessing phylogenetic affinities and species delimitations in Klebsormidiales (Streptophyta): nuclear-encoded rDNA phylogenies and its secondary structure models in Klebsormidium, Hormidiella, and Entransia. Journal of Phycology 44:183-195.
THOMPSON, R.H. \& WUJEK, D.E. 1992. Printzina gen. nov. (Trentepohliaceae), incluinding a description of a new species. Journal of Phycology 28:232-237.

TRACANNA, B.C. 1989. Trentepohliales (Chlorophyta): el género Trentepohlia Martius para las províncias de Salta y Tucumán (Argentina). Lilloa 37:47-59.

UHER, B., ABOAL, M. \& KOVÁČIK, L. 2005. Epilithic and chasmoendolithic phycoflora of monuments and buildings in South-Eastern Spain. Cryptogamie, Algologie 26:275-358.

VISCHER, W. 1960. Reproduktion und systematische Stellung einiger Rinden- und Boden-algen. Schweiz. Z . Hydrologie 22:330-349. 